\title{
Pengaruh Model Pembelajaran Problem Based Learning Berbantuan Audio Visual Terhadap Penguasaan Kompetensi Pengetahuan IPA
}

\author{
Kadek Hery Okta Rivaldi ${ }^{*}$, DB.Kt. Ngurah Semara Putra ${ }^{2}$, I Ketut Adnyana Putra ${ }^{3}$
}

1,2,3 Jurusan Pendidikan Guru Sekolah Dasar (PGSD), Universitas Pendidikan Ganesha, Singaraja, Indonesia.

\author{
A R T I C L E I N F O \\ Article history: \\ Received 13 February 2018 \\ Received in revised form \\ 20 March 2018 \\ Accepted 20 April 2018 \\ Available online 18 May \\ 2018 \\ Kata Kunci: \\ Problem Based Learning, \\ Media Audio Visual, \\ Penguasaan Kompetensi \\ Pengetahuan IPA. \\ Keywords: \\ Problem Based Learning, \\ Audio Visual Media, \\ Mastery of Knowledge \\ Science Competency.
}

\begin{abstract}
A B S T R A K
Penelitian ini bertujuan untuk mengetahui perbedaan yang signifikan penguasaan kompetensi pengetahuan IPA kelompok siswa yang dibelajarkan dengan model pembelajaran problem based learning berbantuan media audio visual dengan kelompok siswa yang dibelajarkan melalui pembelajaran konvensional pada siswa kelas IV SD Gugus Dewi Sartika Denpasar Tahun Ajaran 2016/2017. Jenis penelitian ini adalah penelitian eksperimen semu dengan rancangan nonequivalent control group design. Populasi penelitian ini adalah seluruh siswa kelas IV SD Gugus Dewi Sartika Denpasar yang berjumlah 374 siswa. Sampel diambil dengan teknik random sampling. Sampel dalam penelitian ini adalah siswa kelas IV SDN 3 Kesiman berjumlah 40 siswa sebagai kelompok yang dibelajarkan dengan model pembelajaran problem based learning berbantuan media Audio Visual dan siswa kelas IV SDN 17 Kesiman berjumlah 40 siswa sebagai kelompok control dengan pembelajaran konvensional. Pengumpulan data dilakukan dengan menggunakan metode tes dalam bentuk tes objektif pilihan ganda biasa dengan empat jawaban. Data yang diperoleh dianalisis menggunakan analisis uji-t. Hasil analisis data diperoleh $\mathrm{t}_{\text {hitung }}=6,573>\mathrm{t}_{\text {tabel }}=2,000$ untuk signifikansi $5 \%$ dan $\mathrm{dk}=78$.
\end{abstract} Berdasarkan kriteria pengujian, maka $\mathrm{HO}$ ditolak dan Ha diterima. Berdasarkan hasil penelitian tersebut dapat disimpulkan bahwa terdapat pengaruh model pembelajaran problem based learning berbantuan media Audio visual terhadap penguasaan kompetensi pengetahuan IPA siswa kelas IV SD Gugus Dewi Sartika Denpasar Tahun Ajaran 2016/2017.

\section{A B S T R A C T}

This study aims to determine the significant differences in the mastery of science knowledge competence group of students who are taught by the model problem based learning of audio visual media with groups of students who are taught through conventional learning in fourth grade students of SD Dewi Sartika Denpasar Clinic School Year 2016/2017. This research type is quasi experiment research with nonequivalent control group design. The population of this study is all students of grade IV SD Dewi Sartika Denpasar Elementary School, amounting to 374 students. Samples were taken by random sampling technique. The sample in this research is the fourth grader of SDN 3 Kesiman amounting to 40 students as the group which is taught by the model problem based learning assisted by Audio Visual media and the fourth grade students of SDN 17 Kesiman is 40 students as control group with conventional learning. The data were collected using a test method in the form of a standard multiple-choice objective test with four answers. The data obtained were analyzed using ttest analysis. The result of data analysis is obtained $t_{\text {value }}=6,573>t_{\text {table }}=2,000$ for $5 \%$ significance and $\mathrm{dk}=78$. Based on testing criteria, $\mathrm{HO}$ is rejected and $\mathrm{Ha}$ accepted. Based on the results of this study can be concluded that there is the influence of problem based learning modeled audio visual media on the mastery of science knowledge competence of fourth grade students SD Gugus Dewi Sartika Denpasar Academic Year 2016/2017. 


\section{Pendahuluan}

Pendidikan merupakan hal yang sangat penting di dalam suatu Negara. Suatu Negara dikatakan maju dilihat dari segi pendidikan. Selain itu Pendidikan merupakan sarana penting untuk menciptakan Sumber Daya Manusia yang berkualitas dan berkompetensi. Maka dari itu sangat penting bagi suatu Negara untuk memberikan pendidikan yang berkualitas dan bermutu kepada warga negaranya. Pendidikan itu sendiri merupakan sebuah usaha sadar dan terencana untuk mewujudkan suasana belajar dan proses pembelajaran bagi siswa agar dapat mengembangkan potensi yang dimiliki. Kurikulum merupakan salah satu unsur yang memberikan kontribusi untuk mewujudkan proses perkembanganya kualitas potensi peserta didik tersebut. Kurikulum 2013 di kembangkan berbasis pada kompetensi sangat diperlukan sebagai instrument untuk mengarahkan peserta didik menjadi; (1) manusia berkualitas yang mampu dan proaktif menjawab tantangan zaman yang selalu berubah; (2) manusia terdidik yang beriman dan bertakwa kepada Tuhan Yang Maha Esa, berakhlak mulia, sehat, berilmu, cakap, kreatif, mandiri; dan (3) warga negara yang demokratis, bertanggung jawab. Pengembangan kurikulum 2013 merupakan langkah lanjutan pengembangan kurikulum berbasis kompetensi yang telah dirintis pada tahun 2004 yang mencangkup kompetensi sikap, pengetahuan, dan keterampilan secara terpadu. Dalam kurikulum 2013 siswa dituntut untuk aktif mencari informasi dan membangun pengetahuannya sendiri.

Dalam proses pembelajaran ada beberapa model-model pembelajaran, salah satunya model problem based learning Menurut Sani (2015:127) problem based learning merupakan pembelajaran yang penyampaiannya dilakukan dengan cara menyajikan suatu permasalahan, mengajukan pertanyaanpertanyaan, memfasilitasi penyelidikan dan membuka dialog. Menurut Giarti (2015) model berbasis masalah merupakan model pembelajaran yang memfokuskan hubungan antara teori dengan praktek. Gunantara (2014) menyatakan bahwa model Problem Based Learning merupakan model pembelajaran yang melibatkan siswa dalam memecahkan masalah nyata.

Menurut Shoimin (2014) Problem Based Learning merupakan model pembelajaran yang mampu melatih dan meningkatkan kemampuan untuk memecahkan masalah yang berpusat pada masalah nyata dari kehidupan yang konkret. PBL juga mampu mengembangkan aktivitas ilmiah siswa melalui diskusi kelompok. Sedangkan menurut Arends (2008) Problem Based Learning merupakan pembelajaran yang menampilkan berbagai masalah yang nyata, sehingga berfungsi sebagai batu lompatan untuk penyelidikan.Dengan menggunakan model problem based learning berbantuan media audio visual, Pengalaman belajar, baik itu yang berupa pengetahuan, keterampilan dan sikap mereka peroleh berdasarkan kesadaran dan kepentingan mereka sendiri. Dari berbagai muatan materi di sekolah dasar, Ilmu Pengetahuan Alam (IPA) merupakan salah satu muatan materi yang sering muncul dalam pembelajaran karena berhubungan langsung dengan lingkungan siswa.

Mata pelajaran IPA adalah usaha manusia dalam memahami alam semesta melalui pengamatan yang tepat pada sasaran, serta menggunakan prosedur dan dijelaskan dengan penalaran sehingga mendapatkan suatu kesimpulan (Susanto, 2013:167). IPA dapat dipandang sebagai produk dan sebagai proses. Secara definisi, IPA sebagai produk adalah kumpulan hasil kegiatan empirik dan analitik yang dilakukan para ilmuan berupa fakta, konsep, prinsip, dan teori-teori. Sedangkan IPA sebagai proses adalah strategi atau cara yang dilakukan oleh para ahli saintis dalam menemukan berbagai hal tersebut sebagai implikasi adanya tentang kejadian-kejadian atau peristiwa-peristiwa alam. Berdasarkan observasi di Gugus Dewi Sartika khususnya pada pembelajaran IPA, belum terlihat adanya motivasi siswa saat mengikuti pembelajaran. Siswa kurang bersemangat dalam mengikuti pembelajaran, karena dalam pembelajaran siswa hanya menerima informasi serta sumber belajar seperti buku-buku maupun lembar kerja siswa yang telah tersedia. Selain itu, sebagian besar siswa belum mengetahui manfaat atau kegunaan dari belajar materi-materi IPA yang disampaikan oleh guru, sehingga cenderung bersikap pasif dalam pembelajaran.alam menemukan berbagai hal tersebut sebagai implikasi adanya tentang kejadiankejadian atau peristiwa-peristiwa alam.

Dengan demikian, pembelajaran yang berlangsung terkesan kaku, dan hal ini juga berpengaruh secara bertahap perolehan kompetensi pengetahuan IPA. Untuk mengatasi hal tersebut, dilakukan penelitian sebagai solusi dalam mengoptimalkan kompetensi pengetahuan IPA. Model Pembelajaran Problem Based Learning pembelajaran yang berbasis masalah sebagai pembelajaran yang diperoleh melalui proses menuju pemahaman akan resolusi suatu masalah. Media audio visual merupakan media yang dapat menampilkan gambar (visual) dan suara (audio) secara bersamaan pada saat mengkomunikasikan pesan atau informasi. Kompetensi merupakan seperangkat pengetahuan, keterampilan, dan perilaku yang harus dimiliki, dihayati dan dikuasai. Menurut Kosasih (2014:13) "kompetensi adalah pernyataan yang menggambarkan penampilan suatu kemampuan tertentu secara bulat, sebagai perpaduan pengetahuan dan kemampuan yang diamati dan diukur untuk menuntaskan kegiatan sehari-hari dengan berhasil." Selanjutnya Yusuf (2015:263) menyatakan bahwa, "kompetensi 
adalah perpaduan skill, tingkah laku dan pengetahuan serta nilai-nilai dasar yang dapat didemontrasikan atau direfleksikan dalam kebiasaan, kemampuan berpikir dan bertindak peserta didik sebagai yang dicapai melalui kegiatan mengajar yang bermakna dan penuh arti."

Dalam Permendikbud No.57 Tahun 2014, ketiga aspek tersebut dinyatakan dalam rumusan kompetensi inti menggunakan notasi yaitu (1) Kompetensi Inti-1 (KI-1) untuk Kompetensi Inti sikap spiritual, (2) Kompetensi Inti-2 (KI-2) untuk Kompetensi Inti sikap sosial, (3) Kompetensi Inti-3 (KI-3) untuk Kompetensi Inti pengetahuan, dan (4) Kompetensi Inti-4 (KI-4) untuk Kompetensi Inti keterampilan.

Kompetensi Inti merupakan kompetensi yang harus dikuasai dan dicapai oleh siswa dalam keseluruhan mata pelajaran dalam satu tingkatannya. Penguasaan kompetensi yang ditekankan dalam penelitian ini mencakup kompetensi pengetahuan(KI-3). Pendidikan IPA diajarkan mulai tingkatan sekolah dasar dan berperan penting dalam keseluruhan proses pendidikan. Muatan materi IPA merupakan sebuah tantangan yang harus dihadapi dan diupayakan sehingga memperoleh kedudukan sejajar dengan seluruh tahapan dalam dunia pendidikan. Menurut susanto (2013:165) "IPA merupakan salah satu mata pelajaran pokok dalam kurikulum pendidikan di Indonesia, termasuk pada jenjang sekolah dasar. Pendidikan ilmu pengetahuan alam merupakan ilmu pengetahuan yang sangat penting untuk dipelajari, khususnya pada anak sekolah dasar. Ilmu pengetahuan alam merupakan faktor-faktor prinsip, hukum dan teori-teori IPA yang dikembangkan di sekolah dasar melalui metode penelitian eksperimen. Ilmu Pengetahuan Alam di SD dapat melatih pemaham siswa terhadap konsep-konsep IPA, melatih Ketrampilan siswa dalam menggunakan alat teknologi sederhana dalam memecahkan suatu masalah yang berkaitan dengan alam sekitar yang pada akhirnya dapat diterapkan pada kehidupan sehari-hari.

Pembelajaran berbasis masalah dapat membuat siswa belajar melalui upaya penyelesaian permasalahan dunia nyata (real world problem) secara terstruktur untuk mengkonstruksikan pengetahuan siswa. Pembelajaran ini menuntut siswa untuk aktif melakukan penyelidikan dalam menyelesaikan permasalahan dan guru berperan sebagai fasilitator dan pembimbing. Pembelajaran akan dapat membentuk kemampuan berfikir tingkat tinggi (higher order thingking) dan meningkatkan kemampuan siswa untuk berfikir kritis. Dalam proses pembelajaran ada beberapa model-model pembelajaran, salah satunya model problem based learning Sani (2015:127) menyatakan, Model Pembelajaran Problem Based Learning merupakan model pembelajaran yang menyampainya dilakukan dengan cara menyajikan suatu permasalahan, mengajukan pertanyaan-pertanyaan, memfasilitasi penyelidikan dan membuka dialog. Permasalahan yang dikaji merupakan permasalahan kontekstual yang ditemukan oleh peserta didik dalam kehidupan sehari-hari. Definisi model pembelajaran berbasis masalah adalah suatu lingkungan belajar dimana masalah mengendalikan proses belajar mengajar. Hal ini berarti sebelum pelajar belajar, mereka diberikan umpan berupa masalah. Masalah diajukan agar pelajar mengetahui bahwa mereka harus mempelajari beberapa pengetahuan baru sebelum mereka memecahkan masalah tersebut. Model problem based learning ini digunakan untuk memecahkan masalah atau menemukan tantangan-tantangan yang dihadapi dalam hidup dan pekerjaan.

Berdasarkan pendapat tersebut dapat dirangkum bahwa Model problem based learning ini juga merupakan suatu pembelajaran yang menantang pelajar untuk nyata di dunia ini. Masalah-masalah ini digunakan untuk menarik rasa keingin tahuan pelajar dan menginisiasikan pokok-pokok perkara. Model ini, mempersiapkan pelajar untuk berpikir kritis, serta untuk menemukan dan menggunakan sumbersumber belajar. Dalam model Problem Based Learning menurut (Sumantri, 2015:44) mempunyai ciri ciri utama yang terdapat dalam model ini. Di antaranya sebagai berikut: (1) Strategi problem based learning merupakan rangkaian aktivitas pembelajaran artinya dalam pembelajaran ini tidak mengharapkan siswa hanya sekedar mendengarkan, mencatat kemudian menghafal materi pelajaran, akan tetapi melalui strategi problem based learning siswa aktif berpikir, berkomunikasi, mencari dan mengolah data dan akhirnya menyimpulkannya; (2) Aktivitas pembelajaran diarahkan untuk menyelesaikan masalah. Strategi problem based learning menempatkan masalah sebagai kata kunci dari proses pembelajaran. Artinya, tanpa masalah tidak mungkin ada proses pembelajaran; (3) Pemecahan masalah dilakukan dengan menggunakan pendekatan berpikir secara ilmiah.

Dalam model problem based learning terdapat sejumlah tujuan, menurut (Sumantri, 2015:44) diantaranya: (1) Adaptasi dan partisipasi dalam suatu perubahan, (2) Aplikasi dari pemecahan masalah dalam situasi yang baru atau yang akan datang, (3) Pemikiran yang kreatif dan kritis dan (4) Adaptasi data holistic untuk masalah- masalah dan situasi - situasi.

Problem based learning secara khusus melibatkan pembelajar bekerja pada masalah dalam kelompok kecil yang terdiri dari lima orang dengan asistent sebagai tutor. Masalah disiapkan sebagai sebagai konteks pembelajaran baru. Analisis dan penyelesaian terhadap masalah itu menghasilkan perolehan pengetahuan dan keterampilan pemecahan masalah. Permasalahan dihadapkan sebelum 
semua pengetahuan relevan diperoleh dan tidak hanya setelah membaca teks atau mendengar ceramah tentang materi subjek yang melatar belakangi masalah tersebut. Audio Visual adalah jenis media yang digunakan dalam kegiatan pembelajaran dengan melibatkan pendengaran atau penglihatan sekaligus dalam satu proses atau kegiatan. Pesan dan informasi yang dapat disalurkan melalui media ini dapat berupa peran verbal dan nonverbal yang mengandalkan baik penglihatan maupun pendengaran.Beberapa contoh media audio-visual adalah, film, video, program TV dan lain-lain. (Rayandra Asyhar, 2012).

Model problem based learning yang dibantu media audio visual pada siswa adalah siswa lebih memahami materi pembelajaran, karena dalam pembelajaran ini guru menitik beratkan siswa kepada masalah dunia nyata kemudian untuk bersama-sama memecahkan masalah yang ada dan siswa lebih mudah mengaplikasikan pengetahuan baru yang didapat dalam dunia nyata yang dibantu dengan media audio visual. Pendekatan saintifik dimaksudkan untuk memberikan pemahaman kepada siswa dalam mengenal dan memahami berbagai materi dengan menggunakan pendekatan ilmiah. Selain itu siswa untuk mendapatkan informasi bisa dari mana saja, kapan saja, dan tidak bergantung pada informasi dari guru.

\section{Metode}

Penelitian ini merupakan penelitian kelas eksperimen dan kelas kontrol yang dilakukan pada kelas IV SD Gugus Dewi Sartika Denpasar semester 2 tahun ajaran 2016/2017. Penelitian kelas eksperimen dilakukan di SDN 3 Kesiman dan penelitain kontrol dilakukan di SDN 17 Kesiman. Tujuan penelitian ini untuk mengetahui pengaruh model pembelajaran Problem Based Learning berbantuan Media Audio Visual terhadap penguasaan kompetensi pengetahuan IPA, dengan variable bebas yaitu model pembelajaran Problem Based Learning berbantuan Media Audio Visual dan variabel terikat adalah penguasaan kompetensi pengetahuan IPA siswa kelas IV SD Gugus Dewi Sartika Denpasar. Penelitian ini dilaksanakan pada kelas IV SD Gugus Dewi Sartika Denpasar tahun ajaran 2016/2017. Pemilihan SD Gugus Dewi Sartika Denpasar sebagai tempat penelitian karena keterjangkauan dan kelayakan. Penelitian ini pada dasarnya bertujuan untuk mengetahui pengaruh model pembelajaran Problem Based Learning berbantuan media Audio Visual terhadap kompetensi pengetahuan IPA siswa, dengan memanipulasi variabel bebas dalam strategi pembelajaran yang digunakan, sedangkan variabel lain tidak bisa dikontrol secara ketat sehingga desain penelitian yang digunakan adalah desain eksperimen semu (quasy exsperiment). Desain eksperimen semu yang digunakan dalam penelitian ini adalah "Non equivalent control group design".

Dalam penelitian ini untuk menentukan subjek penelitian langkah awal dalam penelitian ini adalah menetukan populasi yang diteliti. Populasi merupakan kelompok objek/subjek dalam penelitian. "Populasi adalah keseluruhan objek/subjek dalam penelitian" (Lestari \& Yudhanegara, 2015:101). Sedangkan menurut Sugiyono (2012:80), mengenai populasi adalah wilayah generalisasi yang terdiri atas obyek/subyek yang mempunyai kualitas dan karakteristik tertentu yang ditetapkan oleh peneliti untuk dipelajari dan kemudian ditarik kesimpulannya. Populasi dari penelitian ini adalah seluruh siswa kelas IV SD Gugus Dewi Sartika Denpasar tahun ajaran 2016/2017. "Sampel adalah bagian dari jumlah dan karakteristik yang dimiliki oleh populasi tersebut" (Sugiyono 2014: 91). Bila populasi besar, dan peneliti tidak mungkin mempelajari semua yang ada pada populasi, misalnya karena keterbatasan dana, tenaga dan waktu, maka peneliti dapat menggunakan sampel yang diambil dari populasi itu. Apa yang dipelajari dari sampel itu, kesimpulannya dapat diberlakukan untuk populasi. Untuk itu sampel yang diambil dari populasi harus betul-betul representative (mewakili). "sampel merupakan suatu factor penting yang perlu diperhatikan dalam penelitian yang kita lakukan. Jadi berdasarkan kedua pendapat diatas maka dapat disimpulkan bahwa sampel adalah perwakilan yang dimiliki populasi yang digunakan dalam penelitian yang dilakukan" (Setyosari, 2015:221).

Teknik yang digunakan dalam pengambilan sampel ini disebut sebagai teknik simple random sampling (sampel acak sederhana). Pengacakan yang dilakukan adalah acak kelas kemudian dilakukan pengundian. Jadi setiap kelas mendapatkan kesempatan yang sama untuk dijadikan sampel. Pemilihan sampel dalam penelitian ini tidak dilakukan pengacakan individu, karena tidak bisa mengubah kelas yang telah terbentuk sebelumnya. Kelas dipilih sebagaimana telah terbentuk tanpa campur tangan peneliti dan tidak dilakukannya pengacakan individu, kemungkinan pengaruh-pengaruh dari keadaan subjek mengetahui dirinya dilibatkan dalam eksperimen dapat dikurangi sehingga penelitian ini benar-benar menggambarkan pengaruh perlakuan yang diberikan.

Cara pengundian dilakukan dengan menulis semua nama kelas IV di seluruh SD Gugus Dewi Sartika Denpasar, pada masing-masing kertas yang jumlahnya 9, kemudian kertas digulung. Gulungan kertas tersebut dimasukkan ke dalam botol dan dikocok. Dilanjutkan dengan mengambil 2 sampel, 2 sampel yang terpilih yaitu sebagai kelompok kontrol dan kelompok eksperimen. Selanjutnya setelah mendapatkan 2 sampel tersebut, peneliti memberikan pre test untuk menyetarakan kelas tersebut dengan 
menggunakan uji-t dengan rumus polled varians. Metode tes adalah suatu metode untuk memperoleh informasi dengan menggunakan tes atau memberikan soal sedangkan metode nontes adalah metode yang digunakan untuk melengkapi data hasil tes yang menjadi lebih akurat seperti dengan cara wawancara, observasi dan kuisioner (Yusuf Muri 2015:92). Data yang diperlukan adalah data tentang Penguasaan Kompetensi Pengetahuan IPA siswa kelas IV SD Dewi Sartika Denpasar. Untuk mengumpulkan data Penguasaan Kompetensi Pengetahuan tersebut digunakan metode tes. Metode tes digunakan untuk memperoleh data tentang Penguasaan Kompetensi Pengetahuan IPA pada sisi aspek kognitif.

Jenis tes yang digunakan dalam penelitian ini adalah tes objektif dalam bentuk pilihan ganda biasa dengan 4 pilihan jawaban (a,b,c dan d), mula-mula dibuat 50 item atau butir soal sesuai dengan kisi-kisi. Soal tersebut kemudian diujicobakan pada kelas yang lebih tinggi. Setelah dianalisir butir soal yang memenuhi syarat digunakan sebagai instrumen penelitian dengan jumlah pertanyaan yaitu 30 butir soal. Setiap item diberi skor 1 bila siswa menjawab dengan benar (jawaban disesuaikan dengan kunci jawaban) dan skor 0 bila siswa menjawab salah. Skor setiap jawaban kemudian dijumlahkan dan jumlah tersebut merupakan skor variable Penguasaan kompetensi pengetahuan IPA. Suatu instrumen penelitian dikatakan baik jika sudah memenuhi dua persyaratan penting, yaitu valid dan reliabel. Uji coba instrumen penelitian dilakukan untuk mendapat gambaran secara empirik dapat tidaknya instrumen tersebut digunakan sebagai instrumen penelitian. Instrumen penelitian yang dihasilkan dalam penelitian ini diuji validitas tes, reliabilitas tes, daya beda tes dan indeks kesukaran.

\section{Hasil dan Pembahasan}

Hipotesis penelitian yang diuji adalah $\mathrm{H}_{0}$ yang berbunyi tidak terdapat perbedaan yang signifikan penguasaan kompetensi pengetahuan IPA antara kelompok siswa yang dibelajarkan menggunakan Model Pembelajaran Problem Based Learning berbantuan Audio Visual dan kelompok siswa yang dibelajarkan menggunakan model pembelajaran konvensional pada siswa kelas IV SD Gugus Dewi Sartika Denpasar Tahun Pelajaran 2016/2017.

Sedangkan hipotesis (Ha) alternatif yang berbunyi: terdapat perbedaan yang signifikan kompetensi pengetahuan IPA kelompok siswa yang dibelajarkan dengan Model Pembelajaran Problem Based Learning berbantuan Audio Visual dan kelompok siswa yang dibelajarkan menggunakan model pembelajaran konvensional pada siswa kelas IV SD Gugus Dewi Sartika Denpasar Tahun Pelajaran 2016/2017. Hasil penghitungan menunjukkan data kompetensi pengetahuan IPA Siswa Kelas IV kelompok eksperimen dengan tertinggi yang diperoleh siswa adalah 96 dan nilai terendah adalah 70 dengan angka rata-rata (mean) sebesar 84,27. Hasil perhitungan menunjukkan data kompetensi pengetahuan IPA Siswa Kelas IV kelompok kontrol dengan tertinggi yang diperoleh siswa adalah 90 dan nilai terendah adalah 50, dengan angka rata-rata (mean) sebesar 72,70. Dari data tersebut diketahui bahwa nilai rata-rata yang diperoleh siswa yang dibelajarkan dengan Model Pembelajaran Problem Based Learning berbantuan Audio Visual dengan kelompok siswa yang dibelajarkan melalui pembelajaran konvensional.

Sebelum dilakukan pengujian hipotesis dengan analisis uji-t, terlebih dahulu harus dilakukan uji prasyarat yang meliputi uji normalitas sebaran data dan uji homogenitas varians. Uji normalitas sebaran data dimaksudkan untuk mengetahui sebaran data berdistribusi normal atau tidak.

Berdasarkan hasil analisis diperoleh harga $\chi^{2}$ hitung $=3,19$ untuk kelompok eksperimen. Harga tersebut kemudian dikonsultasikan dengan harga $\chi^{2}$ tabel dengan $\mathrm{dk}=5 \mathrm{dan}$ taraf signifikansi 5\% sehingga diperoleh harga $\chi^{2}$ tabel $=11,070$. Karena $\chi^{2}$ hitung $=3,19<\chi^{2}$ tabel $(\alpha=0,05)=11,070$ maka $\mathrm{H}_{0}$ diterima (gagal ditolak). Ini berarti sebaran data kompetensi pengetahuan IPA kelompok eksperimen berdistribusi normal. Sedangkan pada kelompok kontrol harga $\chi^{2}$ hitung $=3,06$. Harga tersebut kemudian dikonsultasikan dengan harga $\chi^{2}$ tabel dengan $\mathrm{dk}=5$ dan taraf signifikansi $5 \%$ sehingga diperoleh harga $\chi^{2}$ tabel $=11,070$. Karena $\chi^{2}$ hitung $=3,06<\chi^{2}$ tabel $(\alpha=0,05)=11,070$ maka $\mathrm{H}_{0}$ diterima (gagal ditolak). Ini berarti sebaran data kompetensi pengetahuan IPA kelompok kontrol berdistribusi normal.

Selanjutnya dilakukan uji homogenitas varians. Uji homogenitas data kompetensi pengetahuan IPA kelompok eksperimen dan kelompok kontrol diperoleh $F_{\text {hitung }}=1,59$. Nilai tersebut kemudian dikonsultasikan dengan harga $F_{\text {tabel }(\alpha=0,05)}=1,70$ dengan dk 39,39. Karena $F_{\text {hitung }}=1,59<F_{\text {tabel }}(\alpha=0,05)=1,70$ maka dapat dikatakan data kompetensi pengetahuan IPA kelompok eksperimen dan kelompok kontrol mempunyai varians yang homogen.

Berdasarkan hasil uji normalitas sebaran data dan uji homogenitas varians dapat diketahui bahwa data yang diperoleh dari kelompok eksperimen dan kelompok kontrol berdistribusi normal dan memiliki varians yang homogen. Karena data yang diperoleh telah memenuhi uji prasyarat, maka uji hipotesis dapat dilakukan dengan menggunakan analisis uji-t.berikut disajikan rekapitulasi hasil analisis data dengan menggunakan uji-t pada Tabel 1. 
Tabel 1. Rekapitulasi Analisis Uji-t

\begin{tabular}{llccccccc}
\hline No & \multicolumn{1}{c}{ Sampel } & $\mathrm{N}$ & $\mathrm{Dk}$ & $\mathrm{X}$ & $\mathrm{S}^{2}$ & $\mathrm{t}_{\text {hitung }}$ & $\mathrm{t}_{\text {tabel }}$ & Status \\
\hline 1 & Kelompok eksperimen & 40 & & 84,27 & 47,89 & & & \\
2 & Kelompok kontrol & 40 & 78 & 72,70 & 76,39 & 6,573 & 2,000 & $\mathrm{H}_{0}$ ditolak \\
\hline
\end{tabular}

Dari hasil analisis diperoleh $t_{\text {hitung }}$ lebih besar dari pada $t_{\text {tabel }}$ yaitu 6,573 $>2,000$. Dengan hasil tersebut maka dapat disimpulkan bahwa $\mathrm{H}_{0}$ yang berbunyi "tidak terdapat perbedaan yang signifikan kompetensi pengetahuan IPA antara kelompok siswa yang dibelajarkan menggunakan Model Pembelajaran Problem Based Learning berbantuan Audio Visual dan kelompok siswa yang dibelajarkan menggunakan model pembelajaran konvensional pada siswa kelas IV SD Gugus Dewi Sartika Denpasar Tahun Pelajaran 2016/2017", ditolak dan $\mathrm{H}_{\mathrm{a}}$ yang menyatakan "terdapat perbedaan yang signifikan kompetensi pengetahuan IPA antara kelompok siswa yang dibelajarkan menggunakan Model Pembelajaran Problem Based Learning berbantuan Audio Visual dan kelompok siswa yang dibelajarkan menggunakan model pembelajaran konvensional pada siswa kelas IV SD Gugus Dewi Sartika Denpasar Tahun Pelajaran 2016/2017", diterima.

Pembelajaran menggunakan model pembelajaran Problem Based Learning berbantuan audio Visual pada muatan materi IPA memberikan kesempatan yang lebih luas kepada siswa untuk mengonstruksikan pengetahuannya melalui berbagai kegiatan bermakna dan teratur yang tentunya menyenangkan bagi siswa pada setiap langkah pembelajarannya. Dengan demikian, perbedaan hasil penguasaan kompetensi pengetahuan IPA dapat terlihat dari langkah pembelajaran yang dilakukan pada kedua kelompok tersebut, hasil analisis uji hipotesis, dan nilai rerata kelompok siswa yang mengikuti pembelajaran menggunakan model pembelajaran Problem Based Learning berbantuan Audio Visual dengan siswa yang mengikuti pembelajaran konvensional.

Hasil temuan pada penelitian ini memiliki persamaan dengan penelitian sebelumnya yang relevan dan memperkuat hasil penelitian yang diperoleh, Hal tersebut didukung hasil penelitian yang diajukan oleh Sastrawa (2013) dengan judul "Pengaruh Model Pembelajaran PBL Berbantuan Media Visual Animasi Terhadap Hasil Belajar IPA Siswa Kelas V SD Gugus II Tampaksiring Gianyar" yang menyatakan bahwa terdapat perbedaan yang signifikan pada hasil belajar IPA siswa antara kelompok siswa yang mengikuti model PBL Berbantuan Media Visual Animasi dengan kelompok siswa yang mengikuti pembelajaran konvensional.

\section{Simpulan dan Saran}

Berdasarkan uji hipotesis diperoleh $\mathrm{t}_{\text {hitung }}=6,573$ sedangkan pada taraf signifikansi $5 \%$ dan $\mathrm{dk}=78$ diperoleh nilai $t_{\text {tabel }}=2,000$ sehingga $t_{\text {hitnung }}=6,573>t_{\text {tabel }}=2,000$. Dengan demikian, hipotesis nol (Ho) ditolak. Hal ini berarti terdapat perbedaan yang signifikan penguasaan kompetensi pengetahuan IPA antara siswa kelas IV di SD Gugus Dewi Sartika Denpasar Tahun Ajaran 2016/2017 yang mengikuti pembelajaran yang menggunakan model pembelajaran Problem Based Learning berbantuan Audio Visual dan siswa yang mengikuti pembelajaran konvensional pada tema Daerah Tempat Tinggalku.

Perolehan hasil perhitungan analisis data yang dilakukan menunjukkan bahwa nilai rata-rata siswa yang mengikuti pembelajaran menggunakan model pembelajaran Problem Based Learning berbantuan Audio Visual $(\bar{X}=84,27)$ dan siswa yang mengikuti pembelajaran konvensional ( $\bar{X}=72,70$ ) memiliki perbedaan sebesar 11,40. Dengan demikian, terdapat pengaruh penguasaan kompetensi pengetahuan IPA antara siswa kelas IV di SD Gugus Dewi Sartika Denpasar Tahun Ajaran 2016/2017 yang mengikuti pembelajaran dengan menggunakan model pembelajaran Problem Based Learning berbantuan Audio Visual dan siswa yang mengikuti pembelajaran konvensional pada tema Daerah Tempat Tinggalku.

Berdasarkan hasil temuan dapat dinyatakan kedua kelompok sampel penelitian yang memiliki kemampuan setara, setelah diberikan perlakuan berupa pembelajaran dengan menggunakan model pembelajaran Problem Based Learning berbantuan Audio Visual dan mengikuti pembelajaran menggunakan pendekatan saintifik diperoleh hasil penguasaan kompetensi pengetahuan yang berbeda. Hal ini dapat dilihat juga dari $\bar{X}$ siswa yang mengikuti pembelajaran menggunakan model pembelajaran Problem Based Learning berbantuan Audio Visual lebih tinggi dibandingkan dengan $\bar{X}$ siswa yang mengikuti pembelajaran konvensional, dalam hal ini adalah pembelajaran yang hanya menggunakan pendekatan saintifik. Perbedaan hasil penguasaan kompetensi pengetahuan dengan perolehan nilai ratarata yang lebih tinggi pada kelompok eksperimen dibandingkan kelompok kontrol disebabkan oleh perlakuan berupa model pembelajaran Problem Based Learning berbantuan Audio Visual dalam muatan materi IPA diberikan pada kelompok eksperimen. 
Adapun saran yang ingin disampaikan melalui penelitian ini, yaitu Kepada guru disarankan agar lebih kreatif untuk memberikan fasilitas berupa sumber belajar dan kesempatan yang lebih besar bagi siswa pada pembelajaran dengan menggunakan Model Pembelajaran Problem Based Learning berbantuan Audio Visual sehingga tercipta pembelajaran bermakna dan menyenangkan bagi siswa. Kepala sekolah hendaknya dapat menggunakan hasil penelitian ini sebagai pendukung sumber belajar guru dalam meningkatkan kualitas pembelajaran dengan menciptakan pembelajaran yang menyenangkan di sekolah sehingga sekolah mampu menghasilkan siswa yang berkualitas. Kepada peneliti lain agar hasil penelitian ini digunakan sebagai referensi untuk melaksanakan penelitian selanjutnya atau menemukan inovasi kegiatan pembelajaran lainnya yang bermakna dan menyenangkan bagi siswa.

\section{Daftar Rujukan}

Agung, A.A. Gede. 2014. Metodologi Penelitian Pendidikan. Malang: Aditya Publishing.

Arikunto, Suharsimi. 2015. Dasar-dasar Evaluasi Pendidikan. Jakarta: PT Bumi Aksara.

Asyhar, Azhar. 2012. kreatif mengembangkan media pembelajaran. Referensi Jakarta.

Candiasa I Made, 2010. Statistik Multivariat Disertai Aplikasi SPSS, Singaraja: Universitas Pendidikan Ganesha.

Dante, nyoman. 2012. Metode Penelitian. Yogyakarta.

Daryanto.2014."Pembelajaran Saintifik". Yogyakarta : Gava Media.

Edwards, S. dan Hummer, M. (2007). Journal Internasional. Problem Baseb Learning in Early Chilhood and Primary Pre-Service Teacher Education: Identifying the Issues and Examining the Benefits. Diunduh pada tanggal 7 Agustus 2018 dari http/:ro.ecu.edu.au/ajte/vol32/iss2/3.

Giarti, S. 2015. Peningkatan Keterampilan Proses Pemecahan Masalah dan Hasil Belajar Matematika Menggunakan Model PBL Terintegrasi Penilaian Autentik Pada Siswa Kelas VI SDN 2 Bengle, Wonosegoro. In Prosiding Seminar Pendidikan Ekonomi dan Bisnis (Vol. 1, No. 1).

Gunantara, Gd. 2014. “Penerapan Model Pembelajaran Problem Based Learning Untuk Meningkatkan Kemampuan Pemecahan Masalah Matematika Siswa Kelas V'. https://ejournal.undiksha.ac.id/index.php/JJPGSD/article/view/2058/1795 (Vol. 2 No. 1).

Kosasih.2015. Strategi Belajar dan Pembelajara.Bandung : Yrama Media.

Koyan, I Wayan. 2007. Statistika Terapan (Teknik Analisis Data Kuantitatif).

Kunandar. 2014. Penilaian Autentik Penilaian Hasil Belajar Peserta Ddidik Berdasarkan Kurikulum 2013. Jakarta: Rajawali Pers.

Maarif, H., \& Wahyudi, W. (2015). Eksperimentasi Problem Based Learning dan CIRC dalam Menyelesaikan Soal Cerita Matematika Siswa Kelas 5 SD. Scholaria: Jurnal Pendidikan dan Kebudayaan, 5(2), 97-115.

Oktaviani. 2014. "Pengaruh Model Problem Based Learning Berbasis Asesmen Kinerja Terhadap Hasil Belajar IPA Ditinjau Dari Gaya Kognitif". E-Jurnal Program Pasca Sarjana Universitas Pendidikan Ganesha (Volume : 4).

Purnama, Arida. 2016. "Pengaruh Problem Based Learning (PBL) Terhadap Hasil Belajar IPA Siswa Kelas IV SD”. E-Jurnal PGSD Universitas Pendidikan Ganesha (Volume 4 halaman: 3).

Sani, Ridwan Abdulah. 2015. Pembelajaran Saintifik untuk Inflementasi kurikulum 2013. Jakarta: PT Bumi Aksara

Setyosari, Punaji. 2015. Metode Penelitian Pendidikan Dan Pengembangan. Jakarta: Pranadamedia Group 
Sigit Mangun Wardoyo, 2015. Pembelajaran Konstruktivisme. Bandung: Alfabeta.

Sudijono, Anas. 2013. Pengantar Evaluasi Pendidikan. Jakarta: PT Rajagrafindo Persada.

Sugiyono, 2013, Metode Penelitian Kuantitatif Kualitatif dan R \& D, Bandung:Alfabeta.

Sugiyono. 2014. Motode Penelitian Administrasi. Bandung : Alfabeta.

Sumantri.2015 .Strategi Pembelajaran. Jakarta: PT Raja Grafindo Persada.

Supriadi, Made. 2012. "Model Pembelajaran Problem Based Learning Berbantuan Media Audiovisual Berpengaruh Terhadap Hasil Belajar IPS Siswa Kelas IV SD Gugus Ubud Gianyar". E-Jurnal mimbar PGSD Universitas Pendidikan Ganesha (halaman: 4).

Supraptinah, U., Budiyono, B., \& Subanti, S. (2015). Eksperimentasi Model Pembelajaran Discovery Learning, Problem Based Learning, Dan Think-Talk-Write Dengan Pendekatan Saintifik Terhadap Kemampuan Pemecahan Masalah Matematika Ditinjau Dari Kemandirian Belajar Siswa. Jurnal Pembelajaran Matematika, 3(10).

Suwandi, Y. (2015). Peningkatan Hasil Belajar IPA Tentang Ekosistem Melalui Metode Problem Based Learning Pada Siswa Kelas V Sekolah Dasar Kabupaten Tana Tidung. Jurnal Pendidikan Dasar Volume 6 Edisis 1 mei 2015, 93 - 102.

Syafriana, D. (2016). Penerapan Model Problem Based Learning (Pbl) Dalam Pendekatan Saintifik Untuk Meningkatkan Hasil. Jurnal Inovasi Pendidikan Dan Pembelajaran Sekolah Dasar, 30 - 43

Samatowa. 2011. "Pembelajaran IPA di Sekolah Dasar". Jakarta:Indek.

Susanto, Ahmad. 2013. (Teori Belajar \& Pembelajaran). Jakarta Prenamedia Group

Wisudawati\&Sulistyowati.2014."Metodologi Pembelajaran IPA”.Jakarta:PT Bumi Aksara.

Wiyani, Novan Ardy. 2013. Desain Pembelajaran Pendidikan: Tata Rancang Pembelajaran Menuju Pencapaian Kompetensi. Yogyakarta: AR-Ruzz Media. 